\title{
The Effect of Fission Product Elements on the Behavior of Uranyl Species in Alkali Chloride Melts: a Contribution towards Reprocessing Spent Oxide Fuels
}

\author{
V. A. Volkovich ${ }^{\mathrm{a}}$, D. E. Aleksandrov ${ }^{\mathrm{a}}$, B. D. Vasin ${ }^{\mathrm{a}}$, D. S. Maltsev ${ }^{\mathrm{a}}$, and T. R. Griffiths ${ }^{\mathrm{b}}$ \\ ${ }^{a}$ Department of Rare Metals and Nanomaterials, Ural Federal University, Ekaterinburg, \\ 620002, Russia \\ ${ }^{\mathrm{b}}$ Redston Trevor Consulting, Ltd., Leeds, LS17 8RF, UK
}

The reactions of uranyl(VI) containing chloride melts with molybdenum, niobium, zirconium and palladium were studied using high temperature electronic absorption spectroscopy. Depending on the nature of the added element uranium is reduced to uranyl(V) and uranium(IV) chloro-species and $\mathrm{UO}_{2}$. Palladium, niobium and zirconium can all be removed from a uranyl(VI)containing melt using molybdenum metal and the melt can then be purified from $\mathrm{Mo}(\mathrm{III})$ ions by bubbling $\mathrm{Cl}_{2}$ gas. Such approach can be employed for removal a number of fission product elements from molten chloride baths during reprocessing spent oxide fuels.

\section{Introduction}

The current primary technology for commercial reprocessing spent uranium nuclear fuels is the solvent extraction (PUREX process). One alternative is pyrochemical reprocessing using high temperature alkali metal chloride-based melts as reaction media. Of the two existing pyrochemical processes for treating spent nuclear fuels (SNF) in chloride melts, developed to pilot plant scale that at ANL, Argonne, USA, uses molten $3 \mathrm{LiCl}-2 \mathrm{KCl}$ eutectic, and the other, at RIAR, Dimitrovgrad, Russia, uses a $\mathrm{NaCl}-\mathrm{KCl}$ equimolar mixture or a $\mathrm{NaCl}-2 \mathrm{CsCl}$ eutectic. The latter has been employed as a low-temperature alternative, particularly for co-deposition of uranium and plutonium dioxides. These approaches use melts containing chloro complexes of uranium in oxidation states (III) and (IV) and oxychloro complexes (uranyl) in oxidation states (VI) and (V). Uranylcontaining melts can be used for producing $\mathrm{UO}_{2}$ or preparing MOX fuel. Fission product elements, as well as container materials in contact with the melt, can affect the speciation and behavior of uranium.

Of all the oxidation states uranium(V) is the least studied and often omitted when the processes taking place in uranyl-containing melts are considered. A detailed study of such melts, however, shows that in many cases uranyl(V) ions are formed when the reactions involve $\mathrm{U}(\mathrm{VI})$ or $\mathrm{U}(\mathrm{IV})$. Uranium forms two oxychloro-species, $\mathrm{UO}_{2} \mathrm{Cl}$ and $\mathrm{UOCl}_{3}$ that potentially can be formed in molten salt media $(1,2)$. For example, the preparation of a mixed uranium( $\mathrm{V}, \mathrm{VI})$ oxychloride $\left(\mathrm{UO}_{2}\right)_{2} \mathrm{Cl}_{3}$ by thermal decomposition of $\mathrm{UO}_{2} \mathrm{Cl}_{2}$ under vacuum or by reacting $\mathrm{UO}_{2}$ with $\mathrm{UO}_{2} \mathrm{Cl}_{2}$ has been reported but it seems that further study of this compound has not been pursued (3).

The usual routes to uranium(V) involve reducing $\mathrm{U}(\mathrm{VI})$ or oxidizing $\mathrm{U}(\mathrm{IV})$ species. Uranyl(V) ions are the intermediate species formed during the cathodic reduction of uranyl(VI) although in some early reports concerning electrodeposition of $\mathrm{UO}_{2}$ from 
fused chlorides the possibility of uranyl(V) formation was overlooked (4-7). The electrochemical and thermodynamic properties of uranyl(V) in individual alkali chlorides and their mixtures was studied in detail by Nekrasova and Komarov (8-11). Uranyl(V)containing melts can be obtained by anodic dissolution of $\mathrm{UO}_{2}$ or by reducing uranyl(VI) ions with uranium dioxide (12).

The addition of carbon into a uranyl(VI)-containing chloride melt results in a twostep reduction to $\mathrm{UO}_{2}$ (deposited on the carbon surface) via intermediate soluble uranyl(V) chloro-species (12). Hydrogen reduction of uranyl(VI)-containing chloride melts ultimately leads to the precipitation of $\mathrm{UO}_{2}$ but a detailed spectroscopy study of the reaction showed that dioxo- and even monooxo-uranium(V) species are formed as the intermediates (13-15). Thermal decomposition of uranyl(VI) chloride in fused salts also yields uranyl(V) species $(1,2,4,6,12)$. Lowering the partial pressure of $\mathrm{Cl}_{2}$ above the melt, e.g., by positioning a $\mathrm{Zr}$ getter in the atmosphere above the melt or sparging the melt with a suitable gas (argon or hydrogen chloride) sweeping $\mathrm{Cl}_{2}$, facilitates the decomposition process $(12,15)$. Under certain conditions uranyl(V) ions are formed when uranium dioxide is reacted with $\mathrm{HCl}$ in alkali chloride melts (16). Increasing the temperature and decreasing the radius of alkali metal cations of the solvent salt favored the oxidation of $\mathrm{UO}_{2}$ and formation of $\mathrm{U}(\mathrm{V})$.

Reaction of $\mathrm{UO}_{2}$ with $\mathrm{Cl}_{2}$ in molten salts leads to the formation of uranyl(VI) ions, although Stromatt noted that at low uranium concentration, when the melt had equilibrated with uranium dioxide, it contained a significant amount of $U(V)$ ions $(17,18)$. Dissolution of $\mathrm{UO}_{2}$ in melts containing aluminum chloride and in the presence of oxygen produces uranyl(VI) species, but under an inert atmosphere U(IV) ions are formed $(17,19,20)$. Komarov and Nekrasova noted that addition of uranium dioxide to a molten alkali chloride, e.g., $\mathrm{NaCl}$, results in partial dissolution of $\mathrm{UO}_{2}$ with the formation of uranyl(V) ions, although the total concentration of uranium in the melt was below 0.005 wt. \% (12). When $\mathrm{UO}_{2}$ is dissolved in molten $\mathrm{MgCl}_{2}$ uranium(IV) oxychloro species, $\mathrm{UO}^{2+}$, are formed (20).

Oxidation of solid U(IV) chloride by oxygen at elevated temperatures first gives uranyl(VI) chloride, with some $\mathrm{UCl}_{5}$ claimed as a by-product, and finally $\mathrm{U}_{3} \mathrm{O}_{8}$ is produced $(21,22)$. Performing this reaction in a molten chloride medium ultimately results in a uranyl(VI)-containing melt (7). In our present preliminary studies of the oxidation of $\mathrm{UCl}_{6}{ }^{2-}$ by $\mathrm{O}_{2}$ in molten alkali chlorides the formation of an intermediate soluble uranyl(V) species was sometimes detected (23).

Thus uranyl(V) species can be formed from uranyl(VI) species in molten salt media by electrochemical reduction and by reaction with certain other elements or their compounds but such studies are few. These concern the reactions of uranyl species upon the addition of or in the presence of certain cations or metallic elements in the melt. The effect of certain fission product elements on the cathodic deposition of $\mathrm{UO}_{2}$ has been studied by Komarov et al. (24,25). In the presence of $\mathrm{Zr}(\mathrm{IV})$ ions the cathodic $\mathrm{UO}_{2}$ product contained $\mathrm{ZrO}_{2}$. When $\mathrm{Nb}(\mathrm{V})$ ions were present in the melt $\mathrm{UO}_{2}-\mathrm{NbO}_{2}$ solid solutions were formed. Immersing a uranium dioxide pellet into a melt containing $\mathrm{Zr}(\mathrm{IV})$ or $\mathrm{Nb}(\mathrm{V})$ ions resulted in the formation of zirconium dioxide or niobium( $\mathrm{V})$ oxide, respectively, and U(IV) chloride due to exchange reactions (24). During the electrolysis of chloride melts containing $\mathrm{UO}_{2}{ }^{2+}, \mathrm{Ru}^{3+}, \mathrm{Rh}^{3+}$ and $\mathrm{Pd}^{2+}$ ions uranium dioxide is 
deposited together with the corresponding platinum metals (25). In the presence of the oxygen-containing molybdenum species $\mathrm{MoO}_{2}{ }^{2+}$, both $\mathrm{UO}_{2}$ and $\mathrm{MoO}_{2}$ are cathodically deposited as individual phases. Some interaction of uranyl(VI) ions with metallic platinum in a NaCl-KCl melt was noted by Smirnov and Skiba but not by Stromatt $(4,26)$. The reaction between $\mathrm{UO}_{2}{ }^{2+}$ and metallic molybdenum in this melt was also observed in the former study but the mechanisms of the reactions were not considered (26).

The present work reports on the reactions taking place in uranyl-containing alkali chloride melts in the presence of a number of common fission product elements using in situ electronic absorption spectroscopy. It is thus also a contribution towards a better understanding of reprocessing SNF using pyrochemical techniques.

\section{Experimental}

The experimental techniques have been described previously $(6,15)$. Electronic absorption spectra were measured using a custom built set-up comprising a fiber optic spectrometer, AvaSpec-2048-2 (Avantes), and an optical furnace, INSTRON SFL TF1726. All experiments were performed under commercial grade argon that had been additionally purified by passing through heated zirconium turnings.

Melts containing uranyl(VI) were prepared by reacting $\mathrm{U}_{3} \mathrm{O}_{8}$ (obtained by thermal decomposition of $\left(\mathrm{NH}_{4}\right)_{4} \mathrm{UO}_{2}\left(\mathrm{CO}_{3}\right)_{3}$ at $700{ }^{\circ} \mathrm{C}$ in air) with $\mathrm{Cl}_{2}$ in various chloride melts. The purity of the elemental molybdenum, zirconium, niobium and palladium used was $99+\%$. Salt mixtures containing palladium(II) chloride were prepared by anodic dissolution of the metal, and those with zirconium(IV) or niobium(V) chlorides were obtained by reacting the corresponding metals with $\mathrm{Cl}_{2}$ gas at elevated temperatures with the subsequent absorption of the gaseous $\mathrm{ZrCl}_{4}$ or $\mathrm{NbCl}_{5}$ in an alkali chloride melt.

\section{Results and discussion}

A series of preliminary experiments was performed on uranyl species in three binary alkali chloride melts with elemental tellurium, palladium, molybdenum, silver, niobium and zirconium, as well as with $\mathrm{Nb}$ (III), (IV) and (V) and $\mathrm{Zr}(\mathrm{IV})$ chloro-species. The major melt chosen was the $\mathrm{NaCl}-2 \mathrm{CsCl}$ eutectic, but melts of $\mathrm{LiCl}, 3 \mathrm{LiCl}-2 \mathrm{KCl}$ and $\mathrm{NaCl}-\mathrm{KCl}$ were also employed: the temperature range used was $550-750{ }^{\circ} \mathrm{C}$. Some results have been reported previously $(15,27)$. The outcome of the reaction and the extent of reduction were found to depend upon the electrochemical properties of the reducing agent.

The reducing properties of the elements studied increases in the order: $\mathrm{Te}<\mathrm{Pd}<\mathrm{Mo} \approx \mathrm{Ag}<\mathrm{Nb}<\mathrm{Zr}$. Tellurium, palladium, silver and molybdenum reduce uranyl(VI) ions to uranyl(V) and uranium dioxide; the amount of $\mathrm{UO}_{2}$ formed increases from tellurium to molybdenum. For example, the reaction of molybdenum with the uranyl ions may be represented as:

$$
\begin{gathered}
3 \mathrm{UO}_{2} \mathrm{Cl}_{4}{ }^{2-}+\mathrm{Mo}+6 \mathrm{Cl}^{-} \rightarrow 3 \mathrm{UO}_{2} \mathrm{Cl}_{4}{ }^{3-}+\mathrm{MoCl}_{6}{ }^{3-} \\
3 \mathrm{UO}_{2} \mathrm{Cl}_{4}{ }^{2-}+2 \mathrm{Mo} \rightarrow 3 \mathrm{UO}_{2}+2 \mathrm{MoCl}_{6}{ }^{3-}
\end{gathered}
$$


Placing the uranyl-containing melt in contact with the more active metals, such as niobium and zirconium, initially also resulted in the formation of uranyl(V) ions and $\mathrm{UO}_{2}$. The niobium and zirconium chlorides formed then reacted with uranium dioxide producing soluble uranium(IV) chloro-species:

$$
\begin{gathered}
\mathrm{ZrCl}_{6}{ }^{2-}+\mathrm{UO}_{2} \rightarrow \mathrm{ZrO}_{2}+\mathrm{UCl}_{6}{ }^{2-} \\
\mathrm{NbCl}_{6}{ }^{2-}+\mathrm{UO}_{2} \rightarrow \mathrm{NbO}_{2}+\mathrm{UCl}_{6}{ }^{2-} \\
\mathrm{NbCl}_{6}{ }^{-}+\mathrm{UO}_{2}+\mathrm{Cl}^{-} \rightarrow \mathrm{NbO}_{2}+\mathrm{UCl}_{6}{ }^{2-}+1 / 2 \mathrm{Cl}_{2}
\end{gathered}
$$

In the presence of excess metallic $\mathrm{Nb}$ or $\mathrm{Zr}$ further reduction of $\mathrm{UCl}_{6}{ }^{2-}$ to $\mathrm{UCl}_{6}{ }^{3-}$ is theoretically possible but observed only with niobium. We conclude that the surface of the zirconium was passivated by an oxide layer that prevented further reaction of $\mathrm{Zr}$ with the uranium(IV) ions.

Despite their high affinity for oxygen, when $\mathrm{Zr}(\mathrm{IV})$ and $\mathrm{Nb}(\mathrm{V})$ ions were added to a melt containing uranyl(VI) they had no effect on uranium speciation even when present in a 10-fold excess. To date we have only found that beryllium(II) chloro species are capable of stripping oxygen atoms from the uranyl(VI) moiety in chloride melts (28). When niobium ions are in their lower oxidation state, (III) and (IV), they behave in a similar manner to $\mathrm{Nb}$ metal, reducing the uranium species to a mixture of $\mathrm{UO}_{2} \mathrm{Cl}_{4}{ }^{3-}$, $\mathrm{UCl}_{6}{ }^{2-}$ and $\mathrm{UO}_{2}$.

The reactions described above open an interesting possibility for removing fission product elements from melts containing uranyl(VI) and other elements. One of the pyrochemical reprocessing flowsheets for spent $\mathrm{UO}_{2}$ based fuels suggests the following sequence of operations after decladding (29):

- Dissolution of the spent fuel by chlorinating it in a molten salt bath. Fission product elements forming volatile chlorides (e.g., molybdenum and antimony) will also be removed in the gas stream during this operation.

- Removal of noble fission product elements ( $\mathrm{Ru}, \mathrm{Rh}$ and $\mathrm{Pd})$ by electrolysis together with some uranium dioxide. Zirconium and niobium will also be removed as dioxides by exchange reactions with $\mathrm{UO}_{2}$ (reactions [3-5]).

- Precipitation of $\mathrm{PuO}_{2}$ followed by cathodic deposition of remaining $\mathrm{UO}_{2}$ or electrolytic deposition of mixed $\mathrm{UO}_{2}-\mathrm{PuO}_{2}$.

In principle, the above mentioned fission product elements can be removed from a melt without employing electrolysis but by, instead, inserting a molybdenum rod of appropriate surface area.

In the presence of molybdenum the noble fission product chloro complexes of ruthenium, rhodium and palladium are reduced to the metallic state, e.g.,

$$
3 \mathrm{PdCl}_{6}{ }^{4-}+2 \mathrm{Mo} \rightarrow 3 \mathrm{Pd}+2 \mathrm{MoCl}_{6}{ }^{3-}+6 \mathrm{Cl}^{-}
$$

and deposited on molybdenum. Zirconium and niobium will be deposited on the uranium dioxide formed by reaction [2] according to the reactions [3-5].

A series of experiments was performed in $\mathrm{NaCl}-2 \mathrm{CsCl}$ melt at $550{ }^{\circ} \mathrm{C}$ to study the distribution of the typical fission product elements, $\mathrm{Pd}, \mathrm{Nb}$ and $\mathrm{Zr}$, during the reaction of 
uranyl-containing melts with metallic molybdenum. The progress of the reaction was followed by in situ electronic spectroscopy measurements. An example of the spectra obtained is given in Figure 1. In the course of the reaction the concentration of palladium, niobium and zirconium in the melt decreased and in the electronic absorption spectra new peaks associated with the absorption of $\mathrm{UO}_{2} \mathrm{Cl}_{4}{ }^{3-}, \mathrm{UCl}_{6}{ }^{2-}$ and $\mathrm{MoCl}_{6}{ }^{3-}$ appeared and their intensity increased. The melt rapidly acquired the green color typical of $\mathrm{UCl}_{6}{ }^{2-}$ species and a black deposit was formed on molybdenum surface. Some of the black solid also found on the bottom of the cell. Table I summarizes the results obtained.

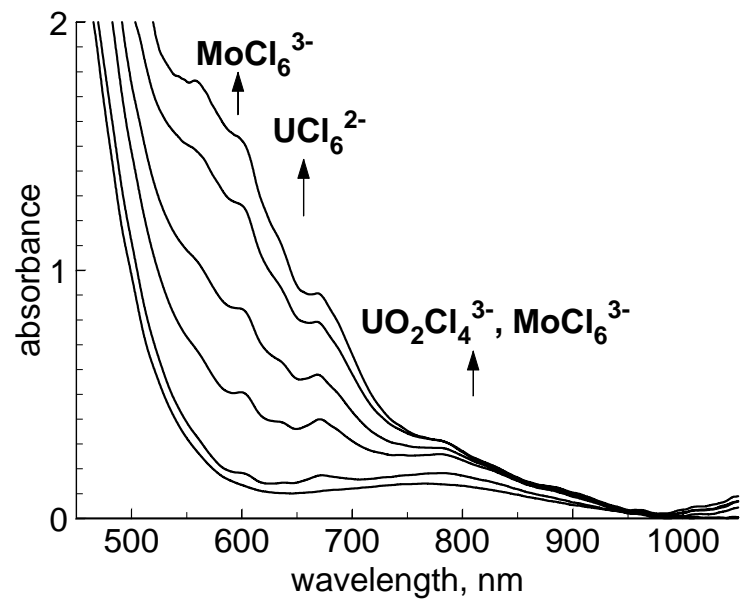

Figure 1. Electronic absorption spectra recorded during the reaction of a $\mathrm{NaCl}-\mathrm{CsCl}-$ based melt containing added $\mathrm{UO}_{2} \mathrm{Cl}_{2}, \mathrm{PdCl}_{2}, \mathrm{NbCl}_{5}$, and $\mathrm{ZrCl}_{4}$ with Mo metal $\left(550{ }^{\circ} \mathrm{C}\right)$. Time after addition of molybdenum (min., bottom to top): 0, 4, 11, 16, 21, and 31, respectively.

TABLE I. Reaction of metallic molybdenum with $\mathrm{NaCl}-2 \mathrm{CsCl}$ melts containing uranyl(VI), palladium(II), zirconium(IV) and niobium(V) ions at $550^{\circ} \mathrm{C}$

\begin{tabular}{|c|c|c|c|c|c|c|c|c|c|}
\hline \multicolumn{4}{|c|}{ Starting melt content, wt. \% } & \multirow{2}{*}{$\begin{array}{l}\text { Reaction } \\
\text { time, min }\end{array}$} & \multicolumn{5}{|c|}{ Final melt content, wt. \% } \\
\hline $\mathbf{U}$ & Zr & Nb & Pd & & $\mathbf{U}$ & $\mathbf{Z r}$ & Nb & Pd & Mo \\
\hline 1.180 & 1.610 & 1.740 & 0.024 & 120 & 0.990 & 1.280 & 1.390 & n.f. & 0.032 \\
\hline 0.280 & 0.476 & 0.407 & 0.006 & 244 & 0.220 & 0.137 & 0.137 & n.f. & 0.269 \\
\hline 0.247 & 0.359 & 0.331 & 0.005 & 26 & 0.180 & 0.147 & 0.145 & n.f. & 0.080 \\
\hline 2.390 & 0.290 & 0.250 & 0 & 155 & 1.690 & n.f. & n.f. & --- & 0.223 \\
\hline 2.297 & 0.269 & 0.220 & 0 & 120 & 1.360 & 0.023 & n.f. & --- & 0.250 \\
\hline 2.391 & 0.150 & 0.110 & 0 & 300 & 0.810 & 0.059 & n.f. & --- & 0.552 \\
\hline
\end{tabular}

n.f. - not found.

Depending on the initial uranium concentration in the melt and that of the chloro complexes of the fission product elements, their concentration in the melt decreased with time. If the starting concentration of $\mathrm{Zr}$ and $\mathrm{Nb}$ was comparable to or greater than the concentration of $\mathrm{U}(\mathrm{VI})$ the reaction was incomplete and essentially stopped when between 30 and $80 \%$ of $\mathrm{Zr}$ and $\mathrm{Nb}$ remained in the soluble state in the melt. If the uranyl(VI) content in the starting melt was substantially greater when that of $\mathrm{Zr}$ and $\mathrm{Nb}$ then the reaction approached completion since the concentration of these two elements in the salt phase decreased significantly, in some cases to undetectable levels. Palladium was reduced to the metallic state and deposited on molybdenum. The fraction of uranium remaining in the melt varied from 34 to $84 \%$ (from the initial) and it should be noted that this value includes all soluble uranium species, i.e., $\mathrm{UCl}_{6}{ }^{2-}, \mathrm{UO}_{2} \mathrm{Cl}_{4}{ }^{3-}$ and $\mathrm{UO}_{2} \mathrm{Cl}_{4}{ }^{2-}$. 
Analysis of the black deposits formed on the surface of molybdenum dipped into the melt showed the presence of uranium, niobium, zirconium and palladium (when palladium was present in the starting melt). The black precipitate on the bottom of the experimental cells consisted of uranium, niobium and zirconium oxides.

Molybdenum(III) chloride in the form of $\mathrm{MoCl}_{6}{ }^{3-}$ is produced as a by-product of the reactions [1], [2] and [6] and in some instances the molybdenum concentration in the melt can reach $0.2-0.5$ wt. \%. To remove the molybdenum species the melt can be sparged with gaseous chlorine to convert $\mathrm{Mo}(\mathrm{III})$ to volatile $\mathrm{MoCl}_{5}$ :

$$
\mathrm{MoCl}_{6}{ }^{3-}+\mathrm{Cl}_{2} \rightarrow \mathrm{MoCl}_{5}+3 \mathrm{Cl}^{-}
$$

This approach was successfully tested at temperatures as low as $550{ }^{\circ} \mathrm{C}$. The reaction was followed spectroscopically and examples of the spectra recorded are shown in Figures 2 and 3. Addition of molybdenum into a uranyl(VI)-containing melt caused the reduction of $\mathrm{U}(\mathrm{VI})$ to uranyl(V) ions and uranium dioxide, and molybdenum was oxidized to Mo(III) ions, reactions [1] and [2], Figure 2. After nearly two hours of reduction the molybdenum rod was raised out of the melt and the melt sparged with chlorine.

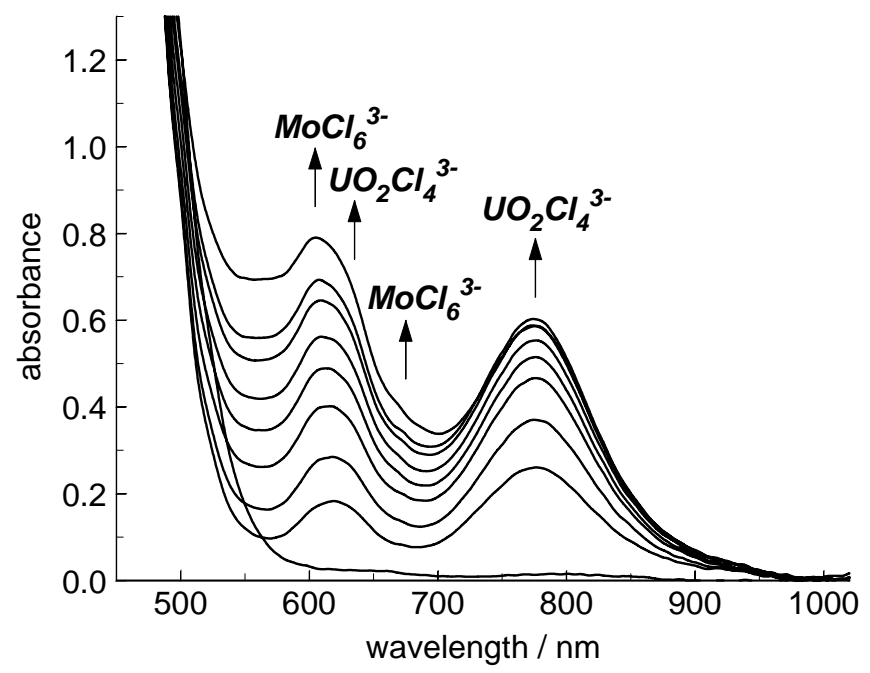

Figure 2. Electronic absorption spectra recorded during the reaction of $\mathrm{NaCl}-\mathrm{CsCl}$ eutectic melt containing added $\mathrm{UO}_{2} \mathrm{Cl}_{2}$ with $\mathrm{Mo}$ metal $\left(550{ }^{\circ} \mathrm{C}\right)$. Arrows indicate the direction in which the spectra changed and the species responsible for the absorption. Time after addition of molybdenum (min., bottom to top): 0, 10, 20, 34, 43, 53, 63, 73 and 108 , respectively.

Bubbling $\mathrm{Cl}_{2}$ through this molybdenum(III) and uranyl(V) containing melt resulted in changes in the absorption spectra, Figure 3. Initially the absorption above $550 \mathrm{~nm}$ decreased (upper plot in Figure 3), indicating that the concentration of $\mathrm{MoCl}_{6}{ }^{3-}$ and $\mathrm{UO}_{2} \mathrm{Cl}_{4}{ }^{3-}$ was also decreased. The profile of the spectral curve then changed and a new prominent broad band appeared at around $760 \mathrm{~nm}$. Previous studies of chloride melts containing molybdenum showed that molybdenum(VI) chloro-species absorb in this region of the spectrum $(30,31)$. It can therefore be concluded that oxidation of Mo(III) to $\mathrm{Mo}(\mathrm{V})$ by chlorine proceeds in two stages, via the intermediate formation of $\mathrm{Mo}(\mathrm{IV})$ : 


$$
\mathrm{MoCl}_{6}{ }^{3-}+1 / 2 \mathrm{Cl}_{2} \rightarrow \mathrm{MoCl}_{6}{ }^{2-}+\mathrm{Cl}^{-}
$$

Molybdenum(IV) ions are then oxidized to $\mathrm{MoCl}_{5}$. Prolonged (90 min.) bubbling of $\mathrm{Cl}_{2}$ through the melt resulted in complete removal of molybdenum as the volatile pentachloride (that partially condenced in the upper cold part of the cell and partially was swept into off-gas stream). Next, subjecting the melt for five minutes to vacuum removed the dissolved $\mathrm{Cl}_{2}$ to produce a clear yellow melt with no absorption above $530 \mathrm{~nm}$, indicating the absence of molybdenum. This was further confirmed since no molybdenum was detected by chemical analysis of samples of the quenched melt.
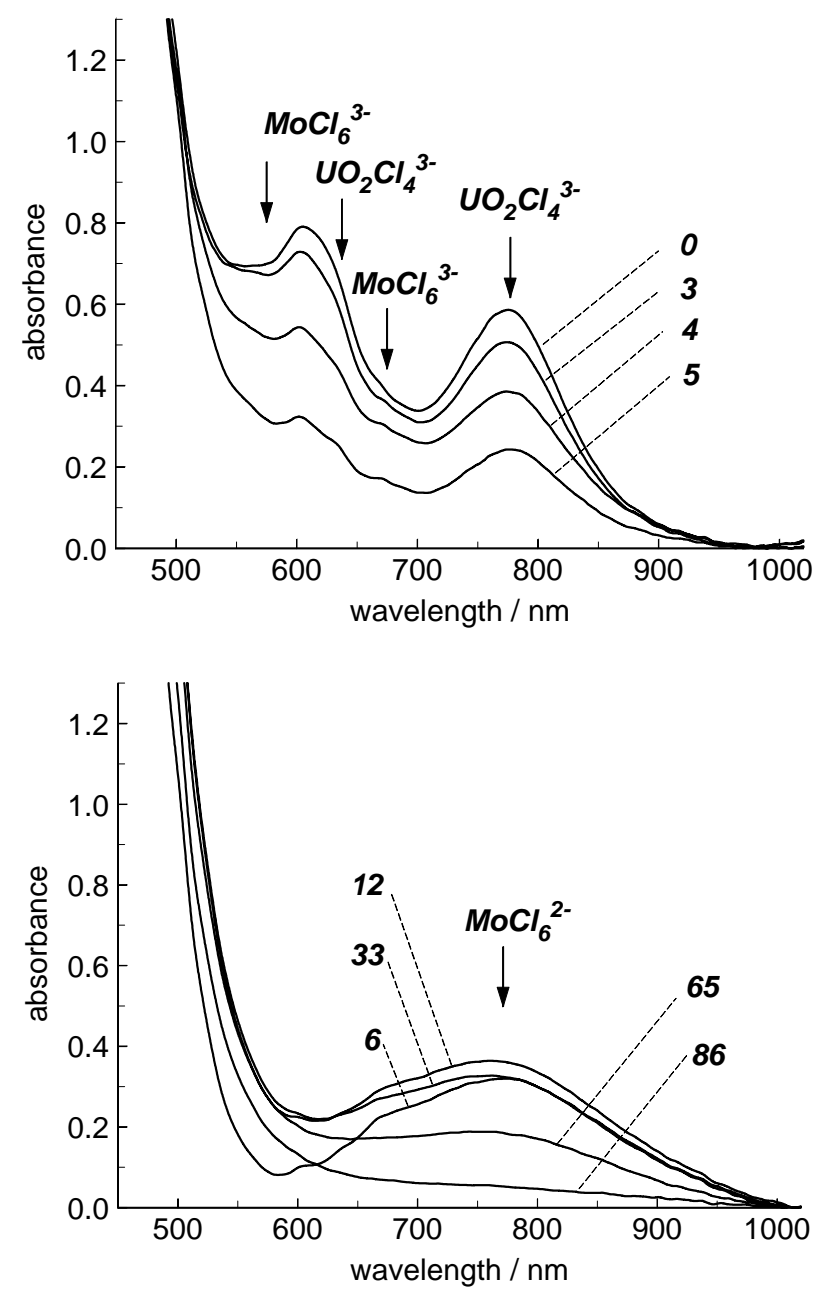

Figure 3. Electronic absorption spectra recorded during bubbling $\mathrm{Cl}_{2}$ through a $\mathrm{NaCl}$ $\mathrm{CsCl}$ melt containing products of the reaction of $\mathrm{UO}_{2} \mathrm{Cl}_{2}$ with Mo metal $\left(550{ }^{\circ} \mathrm{C}\right)$. Arrows indicate the direction in which the spectra changed and the species primarily responsible for the absorption. Time of $\mathrm{Cl}_{2}$ bubbling (in min.) is given for each spectrum.

During this operation soluble uranyl(V) species were oxidized back to uranyl(VI) and the $\mathrm{UO}_{2}$ that was formed during the reduction and fell off the molybdenum rod, which was eventually dissolved:

$$
\mathrm{UO}_{2} \mathrm{Cl}_{4}^{3-}+1 / 2 \mathrm{Cl}_{2} \rightarrow \mathrm{UO}_{2} \mathrm{Cl}_{4}{ }^{2-}+\mathrm{Cl}^{-}
$$




$$
\mathrm{UO}_{2}+\mathrm{Cl}_{2}+2 \mathrm{Cl}^{-} \rightarrow \mathrm{UO}_{2} \mathrm{Cl}_{4}^{2-}
$$

The resulting melt contained only $\mathrm{UO}_{2} \mathrm{Cl}_{4}{ }^{2-}$ ions; confirmed since the average oxidation state of uranium (determined by the red-ox titration of the quenched melt samples) was around 5.8.

If the melt had contained some $\mathrm{UCl}_{6}^{2-}$ ions (e.g., formed in the presence of zirconium or niobium reactions [3-5]) these can be oxidised to uranyl(VI) species by sparging the melt with a gas mixture of chlorine and oxygen:

$$
\mathrm{UCl}_{6}{ }^{2-}+\mathrm{O}_{2} \rightarrow \mathrm{UO}_{2} \mathrm{Cl}_{4}{ }^{2-}+\mathrm{Cl}_{2}
$$

This approach is described in the literature and was also successfully tested in our laboratory (7).

Thus a uranyl-containing melt can be purified from a number of fission product elements by the simple addition of molybdenum metal and without applying any electric current. We particularly note that elements more electropositive than molybdenum (e.g., $\mathrm{Pd}$ ) and more electronegative (e.g., $\mathrm{Zr}$ and $\mathrm{Nb}$ ) can be removed in one operation. Since some of the uranium is lost from the melt due to reaction [2] such an approach can be applied only to reprocessing spent mixed oxide fuel from fast neutron reactors that contains natural or depleted uranium of low economical value.

\section{Conclusions}

The behavior of uranyl(VI) species was studied in chloride melts in the presence of molybdenum, zirconium, niobium and palladium. Addition of molybdenum to a uranyl(VI) containing melt results in reduction of uranium to uranyl(V) and solid $\mathrm{UO}_{2}$ (deposited on molybdenum surface). In the presence of palladium, niobium and zirconium species in the melt they also will be removed in the form of $\mathrm{Pd}, \mathrm{ZrO}_{2}$ and $\mathrm{NbO}_{2}$. Thus employing molybdenum metal alone the melt can be purified from a number of fission products (noble metals, zirconium and niobium) without applying electric current. Resulting melt would contain molybdenum(III), uranyl(V) and uranium(IV) chloro-species. Sparging the melt with chlorine allows to remove molybdenum (in the form of volatile $\mathrm{MoCl}_{5}$ ) and converts uranyl(V) back to uranyl(VI). In the presence of oxygen in the gas stream uranium(IV) species will also be oxidized to uranyl(VI).

\section{References}

1. M. D. Adams, D. A. Wenz and R. K. Steunenberg, J. Phys. Chem., 67, 1939 (1963).

2. D. A. Wenz, M. D. Adams and R. K. Steunenberg, Inorg. Chem., 3, 989 (1964).

3. E. H. P. Cordfunke, G. Prins and P. van Vlaanderen, J. Inorg. Nucl. Chem., 39, 2189 (1977).

4. R. W. Stromatt, J. Electrochem. Soc., 110, 1277 (1963).

5. T. Nagai, T. Fujii, O. Shirai and H. Yamana, J. Nucl. Sci. Technology, 41, 690 (2004). 
6. V. A. Volkovich, D. E. Aleksandrov, B. D. Vasin, T. K. Khabibullin, I. B. Polovov and T. R. Griffiths, in Molten Salts and Ionic Liquids 16, D. Fox, H. De Long, P. Trulove, R. Mantz, R. Hagiwara and S. Dai, Editors, ECS Transactions, 16, Iss. 49, 325 (2009).

7. D. L. Hill, J. Perano and R. A. Osteryoung, J. Electrochem. Soc., 107, 698 (1960).

8. N. P. Nekrasova and V. E. Komarov, Radiokhimiya, 25, 233 (1983) (in Russian).

9. V. E. Komarov and N. P. Nekrasova, Elektrokhimiya, 17, 952 (1981) (in Russian).

10. V. E. Komarov and N. P. Nekrasova, Elektrokhimiya, 17, 1263 (1981) (in Russian).

11. V. E. Komarov and N. P. Nekrasova, Elektrokhimiya, 17, 488 (1981) (in Russian).

12. V. E. Komarov and N. P. Nekrasova, Radiokhimiya, 22, 260 (1980) (in Russian).

13. A. Avogadro, V.V. Dandolo and S. Krawczynski. UK Patent 1084340, Filed 10 December 1964, Issued 20 September 1967.

14. V. A. Volkovich, B. D. Vasin, D. E. Aleksandrov and T. K. Khabibullin, Rasplavy (Melts), Iss. 5, 27 (2009) (in Russian).

15. V. A. Volkovich, D. E. Aleksandrov, T. R. Griffiths, B. D. Vasin, T. K. Khabibullin and D. S. Maltsev, Pure Appl. Chem., 82, 1701 (2010).

16. V. A. Volkovich, I. B. Polovov, B. D. Vasin, T. R. Griffiths, C. A. Sharrad, I. May and J. M. Charnock, Z. Naturforsch., 62a, 671 (2007).

17. V. A. Volkovich, A. I. Bhatt, I. May, T. R. Griffiths and R. C. Thied, J. Nucl. Sci. Technol., Suppl. 3, 595 (2002).

18. R. W. Stromatt, J. Inorg. Nucl. Chem., 27, 2331 (1965).

19. M. Blander and Z. Nagy, Z. Naturforsch., 38a, 116 (1983).

20. S. Dai, L. M. Toth, G. D. Del Cul and D. H. Metcalf, J. Phys. Chem., 100, 220 (1996).

21. J. van Wazer and G. John, J. Am. Chem. Soc., 70, 1207 (1948).

22. B. Kanellakopulos and H. Parthey, J. Inorg. Nucl. Chem., 28, 2541 (1966).

23. D. E. Aleksandrov, D. S. Maltsev, V. A. Volkovich and B. D. Vasin, in Proc. XVII Int. Conf. Prior. Dir. Sci. Tech., Part 2, p. 141, USTU-UPI, Ekaterinburg (2010) (in Russian).

24. V. E. Komarov, N. P. Borodina, Z. S. Martem'yanova, Radiokhimiya, 37, 326 (1995) (in Russian).

25. V. E. Komarov, N. P. Borodina, V. V. Smolenskii, Radiokhimiya, 45, 506 (2003) (in Russian).

26. M. V. Smirnov and O. V. Skiba, in Electrochemistry of Molten Salt and Solid Electrolytes, Iss. 4 p. 17, Inst. Electrochem. UBAS USSR (1963) (in Russian).

27. V. A. Volkovich, D. E. Aleksandrov, B. D. Vasin, T. K. Khabibullin and D. S. Maltsev, Rasplavy (Melts), Iss. 6, 68 (2009) (in Russian).

28. V. A. Volkovich, I. May, T. R. Griffiths, J. M. Charnock, A. I. Bhatt and B. Lewin, J. Nucl. Mater., 344, 100 (2005).

29. B. D. Vasin and V. A. Volkovich, Non-aqueous Methods of Reprocessing Spent Nuclear Fuels, p. 36, USTU-UPI, Ekaterinburg (2009) (in Russian).

30. V. A. Volkovich, D. A. Danilov, I. B. Polovov, B. D. Vasin, T. R. Griffiths, D. E. Aleksandrov, O. A. Tropin and D. V. Tsarevskii, in Molten Salts 15, R. Mantz, H. De Long, D. Fox, R. Hagiwara, G. Stafford and P. Trulove, Editors, ECS Transactions, 3, Iss. 35, 555 (2007).

31. V. A. Volkovich, B. D. Vasin, O. A. Tropin, D. A. Danilov and S. P. Raspopin, Russian Metallurgy, Iss. 2, 150 (2010). 